\title{
FATHOM
}

\section{Bathsheba's Lost Hat and Metonymic Substitution: Objects in Far from the Madding Crowd}

Le chapeau perdu de Bathsheba et la substitution métonymique : Les objets dans Far from the Madding Crowd

\section{Annie Ramel}

\section{OpenEdition}

\section{Journals}

Electronic version

URL: http://journals.openedition.org/fathom/504

DOI: $10.4000 /$ fathom.504

ISSN: 2270-6798

\section{Publisher}

Association française sur les études sur Thomas Hardy

Electronic reference

Annie Ramel, «Bathsheba's Lost Hat and Metonymic Substitution: Objects in Far from the Madding Crowd », FATHOM [Online], 3 | 2016, Online since 30 April 2016, connection on 02 May 2019. URL http://journals.openedition.org/fathom/504; DOI : 10.4000/fathom.504 


\title{
Bathsheba's Lost Hat and Metonymic Substitution: Objects in Far from the Madding Crowd
}

\author{
Le chapeau perdu de Bathsheba et la substitution métonymique : Les objets dans \\ Far from the Madding Crowd
}

\section{Annie Ramel}

Ce dont il s'agit dans le désir, c'est d'un objet, non

d'un sujet ("What is involved in desire is an object, not a subject", Lacan 1991, 203, my translation).

Objects have a certain prominence in Far from the Madding Crowd, which opens with a vision of Bathsheba perched on the top of a heap of household goods carried on an "ornamental spring wagon" (Hardy 1986, 9). Oak, glancing over a hedge, spies on the scene while the driver has to retrace his steps to retrieve a lost object (the tailboard of the wagon). All these objects, including the "oblong package" containing a small lookingglass, are part of the girl's reality: each has a definite function. Some may be lost, like Bathsheba's hat blown off by the wind, which Oak finds and returns to her. Very different are the objects treasured by Boldwood in a locked cabinet: the "extraordinary collection of articles" discovered after his arrest, the dresses, silks, satins, poplins, velvets, muffs, bracelets, lockets and rings which Boldwood had "brought home by stealth" (294), serve no purpose at all, aside from the secret enjoyment he derives from them. They could be interpreted in a Freudian perspective as fetish objects.

2 These two antithetical scenes, one opening the novel and the other near its closure, point to a polarity around which I will organize this paper: one pole being a series of objects that may be used, lost, found, retrieved, and the other objects that can only be found, because they represent the attempt to deny that there is such a thing as lack in human experience. In the latter series, the object is a surplus object, like for instance the Valentine card bought by Bathsheba, which she does not know what to do with ('“Dear me - I had nearly forgotten the valentine I bought yesterday,' she exclaimed at length. 
'Valentine! Who for, miss?' said Liddy. ‘Farmer Boldwood?'”, Hardy 1986, 78). It is in excess of reality, and will tragically disrupt its coherence. Of course the reader will already have surmised that objects work in the novel as metonyms for the character who stands as the main object of desire: Bathsheba Everdene, the woman coveted by three men.

Let me first turn to Gabriel Oak, the shepherd who is no angel if one considers his propensity to indulge in mild forms of voyeurism. To him Bathsheba is a true "object", in the sense that an object is, etymologically, an ob-jectum, a "thing thrown before" (OED): something to follow in an unending quest, a bright star that remains inaccessible, on the horizon of his desire. "I've danced at your skittish heels, my beautiful Bathsheba, for many a long mile, and many a long day" (Hardy 1986, 303) are his words when he realizes she is willing to marry him ${ }^{1}$. Bathsheba, a "thing thrown before" him, has been drawing him onward, in pursuit of her, like a magnet. But we should not be mistaken: the star Gabriel is in love with is a fallen star, in a post-lapsarian world. We are not in the Golden Age, as Annie Escuret remarks (Escuret 149). When Gabriel first catches sight of Bathsheba on a cold wintry night, he first believes that what he sees is "a star low down behind the outskirts of the plantation", but soon realizes that it is but an artificial light (Hardy 1986, 15). The radiance attracting him is no bright star high up or low down in the sky, but a lantern in a "shed" occupied by two girls tending a cow and a calf. Oak goes down the slope of the hill and steps on the roof of the shed, which is "almost level with the ground". Then, "leaning down upon the roof" (15), he peeps through a hole and discovers the graceful girl inside. The movement of his body, of his gaze as well as of ours, is downward. We are in a fallen world - an idea also connoted by the signifier "shed". There one can only enjoy substitutes for the real thing-in-itself, which is missing (Ramel 2015, 75-76).

4 Another point to be made concerns the hat lost by Bathsheba, mentioned analeptically in the conversation between the two women overheard by Oak ("Well, my hat is gone [...] It went over the hedge I think. The idea of such a slight wind catching it", Hardy 1986, 16). The hat is discovered by Oak in the following chapter, but his intention to restore "the missing article" to its owner is delayed by his embarrassment at the girl's unorthodox riding position. The episode of the missing hat is an ellipsis in the narrative, and as such it hollows out a vacant space, in likeness, one might say, to the hollow inside a hat. I wish to argue that this void is the matrix out of which desire will grow in the novel, for Gabriel in particular, but also for Bathsheba. Indeed the primordial object of desire is always already lost, its place has been hollowed out ever since the subject entered symbolic exchange: and this initial loss is the condition for him to be able to engage in the metonymic quest after an object that will always be missing - although there may be plenty of ersatz objects to obtrude the void temporarily. Lacan has a coined a formula for this initial void, objet petit $a$, an object which "inscribes the presence of a hollow which any object may come into" (Dor 185). Objet a, writes Sarah Kaye, may be defined as "a pure deficit in the symbolic order that does not have any imaginary protrusion to fill it out [...] As such, it acts as a vacuum, sucking other objects into its place (Kaye 56). Such a vacuum is delineated in the novel by the missing scene about the lost hat, and it is to be noted that Lacan has compared objet a to what he calls an en-forme, a hat-mould, both as the form around which a hat is shaped and as the hollow thus produced: "Le champ de l'Autre est [...] en forme de a. Cet en-forme s'inscrit dans une topologie où il se présente au niveau de ce champ comme le trouant" (Lacan 2006, 301)². 
The mould is an important image in the novel. Before we move on to the scene in which Troy leaves in the air "almost a mould of Bathsheba's figure", I would like to show that, where Boldwood is concerned, that normal economy of desire does not work. For one thing, Boldwood's desire is kindled by an uncanny object, a surplus object, the Valentine card that has found its way to his mantelshelf. Bathsheba's error has consisted in filling the "small oval enclosure" in the centre of the card, the space left blank so that the sender may insert tender words there (Hardy 1986, 78) - she has somehow filled the hole, the en-forme that should have remained empty. In the chapter that follows ("Effect of the Letter - Sunrise"), the reader is struck by the spatial inversion that takes place, the east and the west changing places as it were. As the day is dawning, Boldwood dresses and walks out "towards the gate of a field to the east". But the rising sun becomes a sunset, and he seems to be walking westward: "the whole effect resembled a sunset as childhood resembles age" (81). Boldwood's whereabouts seem to have become confused, with all distinctions annulled: between east and west, indoors and outdoors, up and down, heaven and earth, light and darkness (81; see Lanone 106). Rather strangely, Boldwood appears to Bathsheba as "a troublesome image", "a species of Daniel in her kingdom who persisted in kneeling eastward when reason and common sense said that he might just as well follow suit with the rest" (Hardy 1986, 78, my emphasis). A textual note points out that "Hardy has mistakenly Daniel face east, when, in fact, Jerusalem would be west of Babylon" (78). Indeed Boldwood is persistently mistaken: he can only be oriented in the etymological sense of the term, that is to say his position can only be eastward. He cannot look westward because what is behind him (the rising sun, the origin) has come to the forefront (Ramel 2015, 72-73).

My interpretation is that Boldwood's subjective position is one that refuses the object as objectum - a "thing thrown before" - because his attention is riveted on an object that lies behind him, the object-cause from which objet petit $a$ is normally extracted, in a process that should leave behind an empty place (the "vacuole" which Lacan compared to the enforme of a hat). Isn't it striking that Boldwood should be conscious of the letter even when it is behind him? ("he was conscious of its presence even when his back was turned upon it", Hardy 1986, 80). One may also ponder over Bathsheba feeling uneasy because she is the cause of Boldwood's party (275). It ensues logically that it is the origin that attracts Boldwood like a magnet. When he receives the Valentine, the signifier "origin" is repeated three times in two pages:

[...] the letter and its dictum changed their tenor from the thoughtlessness of their origin to a deep solemnity, imbibed from their accessories now [...] The letter must have had an origin and a motive [...] She was a misty shape, and well she might be, considering that her original was at that moment sound asleep and oblivious of all love and letter-writing under the sky (80-81, my italics).

Indeed it is possible to read the Valentine scene as a "primal scene", the erotic charge being rather obvious with words that play on two registers, that of hand-writing, and that of sexuality:

Somebody - some woman's hand had travelled softly over the paper bearing his name; her unrevealed eyes had watched every curve as she formed it. Her brain had seen him in imagination the while. Why should she have imagined him? Her mouth - were the lips red or pale, plump or creased - had curved itself to a certain expression as the pen went on (80, my italics).

"Curve" is used first with reference to handwriting, and then with reference to a woman's body. "Softly" refers to writing but has sexual undertones. A sexual significance may be 
overheard in "as the pen went on". Boldwood appears as a creature born of her imagination ("why should she have imagined him?"), as though conceived by her, couched on "the paper bearing his name" (my italics). What fascinates Boldwood is the opacity of the "sexual night" (Quignard), the unfathomable mystery of the womb wherein he fancies lies his origin. Would the letter have exerted the same fascination on him had it been signed? I very much doubt it. The unsigned letter appeals to his deepest desire: to return to the origin - to the east. And the east, paradoxically, takes him to the setting sun (the "Occident", the locus of death), for the womb and the tomb are one and the same thing in the world of tragedy where movement is impossible. Boldwood has no horizon but the object-cause, the primordial object "locked" within Bathsheba (Ramel 2015, 73-74).

9 So I can now move on to Bathsheba and Troy as objects of desire for each other: Troy is clearly a desired object for Bathsheba - rather unexpectedly, it is Troy, not Bathsheba, who appears as a red "spot", in an inversion of perspective that gives us the feminine view of things. Symmetrically, one might say, Bathsheba is an object coveted by Troy. A sentimental novel would posit a "mutual fitness" (Eliot 368) or, to use Rosemarie Morgan's words, "a consonance in sexual relationships" that would lead to a happy ending, with the lovers "getting-married-and-living-happily-ever-after" (Hardy 2000, $\mathrm{xxx}$ ). Here, on the contrary, we are told from the outset that Troy will "miss" Bathsheba ("I shall miss you every time by one hair's breadth", Hardy 1986, 144, my emphasis): the words have a prophetic ring, for Bathsheba and Troy will indeed "miss" each other, i.e. fail to be one through love - which is, after all, the common lot for those "poor devils of both sexes, getting into such messes" all over the world (Woolf 174). No one knew better than Hardy that, to use Lacan's provocative phrasing, "there is no sexual relationship" (a rather problematic translation of "il n'y a pas de rapport sexuel", Lacan 2001, 455). The sword scene may be interpreted in such a light, as evidence of Bathsheba remaining forever out of reach, an untouchable, ungraspable, unviolable object of desire. Such is the perspective in which I wish to consider the well-known passage describing the episode:

It may safely be asserted with respect to the closeness of his cuts, that had it been possible for the edge of the sword to leave in the air a permanent substance wherever it flew past, the space left untouched would have been almost a mould of Bathsheba's figure" (Hardy 1986, 145).

10 I know this approach has seldom been adopted) - but that is no reason for refusing to attempt it. I of course fully endorse the readings that point to the "position of captivity" Bathsheba finds herself in (Friedman 389), and analyze the scene as part of the "taming" she is subjected to. She is undeniably "enclosed" within the "circling gleams" of Troy's sword (Hardy 1986, 144) - the ring forced on to her finger by Boldwood will be a similar attempt to contain/constrain her within the circle of male domination. I agree with Catherine Lanone that Troy "cuts [Bathsheba] into shape" and that Hardy, subverting the myth of Pygmalion, shapes Bathsheba into an ideal woman in order to petrify her (Lanone 107). But that is only one side of things. For the scene is complex, enigmatic, it allows a plurality of readings. Right from the start an oxymoron, "a dim spot of artificial light" (Hardy 1986, 143), points to the difficulty of interpretation. Then many words are problematic. Troy, we are told, gives a "performance" in front of Bathsheba ("if you are [afraid] I can't perform", 144, "never had he been in such a splendid temper for the performance", 145). Is he merely doing a piece of routine work, as a professional soldier, as though the exercise were part of a drill, or is the performance theatrical? Another reading would take "performance" as the sort of achievement expected of a male by his 
female partner. The first meaning of "performance" can be further divided into two submeanings: "performing" for a soldier could be taken as "drilling", or as killing people in a real battle - obviously Troy's only victim here is a caterpillar spitted on his sword. So there is a full range of possible meanings, from killing to acting. "Performance" as "acting" reappears several times in a later episode, when Troy, who is believed to be dead, is the leading actor in "The Royal Hippodrome Performance of Turpin's Ride to York and the Death of Black Bess" (Hardy 1986, 259, 262, 264). Then, with the benefit of hindsight, we know for certain that Troy's first "performance" was more in the nature of acting than of killing. All the more so as the circus episode insists on the fictional dimension of the "performance": "Of course he is not really shot, Jan - only seemingly!" exclaims Joseph Poorgrass to his friend Jan Coggan (264), thereby restoring an awareness of the "willing suspension of disbelief" (Samuel Taylor Coleridge, 1817) which any reader of fiction must consent to. It is that capacity to allow for a certain flicker of meaning, a vacillation between belief and disbelief, which Boldwood had cruelly lacked when he received the Valentine and its injunction: he should have disbelieved it, and taken it for what it was, a mere joke. Seen in retrospect, the performance amid the ferns was but a show, Bathsheba had only seemingly been pared alive two hundred and ninety-five times. After all, when she emerges from the hollow amid the ferns, she is "untouched", she is safe.

"Safe": here is another problematic word. Bathsheba, Troy explains, had been "perfectly safe" (Hardy 1986, 146) during the sword exercise, thanks to his telling her a fib (which she took at face value). He had made sure of her "safety" (146). "It may be safely asserted", writes the narrator, that "had it been possible for the sword to leave in the air a permanent substance [...] the space left untouched would have been almost a mould of Bathsheba's figure" (145, my italics). The sentence displaces the question of "safety" from the diegetic level to that of the narrative, and opens a hiatus between the "safety" of the narrator's assertion and various forms of modalisation ("It may be...", "had it been possible [...] would have been almost a mould", my italics). How then are we to interpret the sentence, and the chapter as a whole? Is Bathsheba "safe" because she is unhurt, "untouched"? Or is she safe because Troy has, through his tricks, "secured" her? "To secure" is the word used by Boldwood, then by Troy, when the former attempts to "sell" Bathsheba to Troy: "'How shall I get you to see how advantageous it will be to you to secure her at once?' 'I don't wish to secure her in any new way"' - Troy's ironical reply implying that he has already "secured" her (180).

How then can one understand the "space left untouched" by Troy's sword, "almost a mould of Bathsheba's figure"? As a "safe" in which she is "secured" by her male partner, or as a void that stands for a radical absence, for her essential inviolability, for the lack of "mutual fitness" between a man and a woman? I incline towards the second option, because there is no such thing as "safety" either in the diegesis or in the narrative: there is no way in which Bathsheba might be "secured", no way in which an ultimate meaning might be guaranteed to the reader. The "thing-in-itself" is definitely lacking. To me the "mould" of Bathsheba's figure is structurally similar to the hat-mould ("en-forme"). of Lacan's en-forme metaphor, it has retained the ambiguity of an object which is both a shape and a void: a form around which a hat is shaped, and the hole produced by the hatmaking operation. The ambiguity is that of objet $a$, which is both a vacuum and the objects "sucked" into it - in an endless attempt to fill it with the metonymic objects substituted for the missing object-cause. The mould of Bathsheba's figure is then both the 
"permanent substance" (Hardy 1986, 145) given by male fantasy to Bathsheba as object of desire, and the lack of any such "substance" - the impossibility of access to that object.

Desire, then, requires the possibility of metonymic substitution. It is by no means insignificant that Troy should impale on his sword a caterpillar which had settled on Bathsheba: for the animal serves as a metonym for the heroine. Beside Troy's cruelty, the hardly disguised death-drive at work here, and the suggestion of rape (made patent by the "rape of the lock", Lanone 107), we should read in this detail that what characterizes the relation between Troy and Bathsheba is the possibility of substitution through metonymy (the caterpillar, contiguous to Bathsheba, representing her metonymically), and synecdoche (the lock of hair as a part standing for the whole). One might say that the heroine is "safe" because the caterpillar suffers in her place. A similar logic is at work in "the Sacrifice of Abraham" (Genesis): just as Abraham was about to sacrifice his son Isaac, God sent him a ram to be sacrificed in his place. The episode seals the Alliance between the Israelites and God, and puts an end to the demand of the Other for human sacrifices what is sacrificed here is in fact the boundless jouissance of the Other. That major advance marks humanity's entrance into an order in which one thing may be substituted for another - that is to say the symbolic order, the order of language - language achieving the substitution of a signifier for the thing-in-itself. The relevance of this to Far from the Madding Crowd is manifest if one remembers that, for Boldwood, no substitution is possible: Bathsheba is his "one delight" (Hardy 1986, 161), not a woman among others but "the single one of their number he had ever closely beheld" (175). Being the objet-cause of his desire, she is, like Polynices for Antigone, irreplaceable, whereas Gabriel Oak feels tied to Bathsheba by "a beautiful thread which it pained him to spoil by breaking, rather than by a chain he could not break" (106). Boldwood's fixation on an irreplaceable object marks the point where we step into the world of tragedy: the point where the slippage of metonymic objects of desire is interrupted - such an interruption being, as Guyomard has argued in his study of Antigone, characteristic of tragedy (Guyomard 41-42).

It is logical then that the disorder Boldwood introduces into the diegesis should affect language, as though his fascination for the origin of the letter (Bathsheba's letter) had somehow blocked the signifying chain, and made the free play of signification impossible. Boldwood's error is to take the letter... to the letter - like Henchard in The Mayor of Casterbridge, who offers to sell his wife like a mare at a fair and is taken at his word (Ramel 84). Language, says Lacan, is "the murder of the thing" ("Le symbole se manifeste d'abord comme meurtre de la chose", Lacan 1966, 319). Not so for Boldwood, and more generally speaking for Hardy's tragic characters, for whom language is the thing: signifier, signified and referent being indissociable, coagulated in a solid, compact mass. The large red seal of the Valentine, with its "capital" words "Marry Me", draws the bachelor's gaze like a magnet, and comes to be incarnated "as a blot of blood on the retina of his eye" (Hardy 1986, 80): the word has become flesh, Boldwood's own flesh a surface written upon - just as the writing on a fence by a religious fanatic in Tess of the d'Urbervilles turns Tess's body into a "tex". As Isabelle Gadoin has shown, the Valentine scene turns textuality into materiality. Thus language becomes "strangely perfomative" (Lanone 106), and Boldwood's secret writing on the packages he keeps locked in a closet, every one of them labelled "Bathsheba Boldwood", is a form of "wishful thinking" that attempts to make language performative (Lanone 106). Boldwood's trying to wrench from Bathsheba her word that she will agree to marry him in six years' time originates in the same desire to make language consist: "But do give your word! [...] You owe it to me!" (Hardy 1986, 286). 
Bathsheba's word is an object to be secured, the very thing Boldwood is craving. It is worth noting that "a game of Prisoners' base" (236), for which the young men of the village are gathering, is a sign heralding the comic resolution: the possibility of play is about to be restored. Playing pranks on one's neighbours (106), indulging in childish games (158), will not be taken seriously any more. The village has been purged of a tragic curse, and it is in language that playfulness has been restored, primarily and most significantly: on awaking after her night spent outdoors, Bathsheba is amused by the school dunce trying to learn by rote a prayer that he does not understand (233). Near the end of the novel, she hears children rehearsing "Lead, Kindly Light" in the church, and envies their unconcern at the meaning of their words (298). It was an excess of meaning that had brought tragedy into Weatherbury. That excess has now been corrected, and a playfulness that might be called "ludism" can again prevail in language, "as the open play of signification, as the free and productive interaction of forms, of signifiers and signifieds, without regard for an original or an ultimate meaning" (Mistacco 375). Tracing the origin of the letter is no longer the order of the day.

Ludism, that is to say textual play, is what the literary text does: "the text is viewed as a game affording both author and reader the possibility of producing endless meanings and relationships" (Mistacco 375, italics added). Hardy's paradox is that his tragic characters are trapped in a world where the word is made flesh, where language becomes incarnated in human bodies (or bodies "intextuated", to use a formula coined by Michel de Certeau), while his writing liberates language, releasing a free flow of words whose ultimate meaning escapes his control, or anybody's control - and that is precisely the reason why we are here discussing his novels. "My values are positively all blanks", wrote Henry James (James 42). The words used by Thomas Hardy are such blanks, which we try to fill with meanings. However hard I try to ascribe a meaning to words like "performance", "safety", "to miss", "mould", "substance", "origin", etc., the text in its opacity resists investigation. The literary text as an object to be enjoyed by a multiplicity of readers bears some resemblance to the mould of Bathsheba's figure: like James's blanks, like the Lacanian en-forme, it provides a "permanent substance" while shaping out an unfathomable void.

\section{BIBLIOGRAPHY}

Dolar, Mladen, A Voice and Nothing More, Cambridge (Mass.): MIT Press, 2006.

Dor, Joël, "L'inconscient structuré comme un langage", Introduction à la lecture de Lacan, 1, Paris: Denoël, 1985.

Eliot, George, The Mill on the Floss (1860), ed. Gordon S. Haight, Oxford: OUP, 1998.

Escuret, Annie, "Le miroir, l'épée et la houlette", Thomas Hardy, Far from the Madding Crowd, ed. Laurence Estanove, Paris: Atlande, 2010, 145-167.

Friedman, Alan, "Innocence, Expansion, and Containment", in Thomas Hardy, Far from the Madding Crowd, ed. Robert C. Schweik, New York: Norton Critical Edition, 1986, 385-392. 
Gadoin, Isabelle, "Le blanc de la lettre dans Far from the Madding Crowd de Thomas Hardy", FATHOM [Online] "The Letter" 1 (2013), <http://fathom.revues.org/180> (last accessed 26 Feb 2016).

Guyomard, Patrick, La jouissance du tragique: Antigone, Paris: Flammarion, 1998.

Hardy, Thomas, Far from the Madding Crowd (1874), ed. Robert C. Schweik, New York \& London: Norton, 1986.

Hardy, Thomas, Far from the Madding Crowd (1874), ed. Rosemarie Morgan, London: Penguin Books, 2000.

James, Henry, The Aspern Papers and The Turn of the Screw, London: Penguin Classics, 1984.

Kaye, Sarah, Slavoj Zizek: A Critical Introduction, Cambridge: Polity Press, 2003.

Lacan, Jacques, Écrits, Paris: Seuil, 1966.

Lacan, Jacques, “L’Étourdit”, Autres Écrits, Paris: Seuil, 2001, 449-507.

Lacan, Jacques, Le Séminaire, livre VIII: “Le transfert”, Paris: Seuil, 1991.

Lacan, Jacques, Le Séminaire, livre XVI: “D’un Autre à l'autre”, Paris: Seuil, 2006.

Lanone, Catherine, "Without Throwing a Nymphean Tissue over a Milkmaid: From Bathsheba Everdene to Tess of the d'Urbervilles", Thomas Hardy: Far from the Madding Crowd, eds. Annie Ramel \& Christian Gutleben, Cycnos 26.2, Paris: L'Harmattan, 2010, 103-110.

Mistacco, Vicky, “The Theory and Practice of Reading Nouveaux Romans: Robbe-Grillet's Topologie d'une cité fantôme", The Reader in the Text, eds. Susan R. Suleiman \& Inge Crosman, Guilford: Princeton University Press, 1980, 371-400.

Quignard, Pascal, La nuit sexuelle, Paris: Flammarion, 2007.

Ramel, Annie, "Texts and Textiles in The Mayor of Casterbridge", De la littérature à la lettre, eds. Adolphe Haberer \& Josiane Paccaud-Huguet, Lyon: PUL, 1997, 75-89.

Ramel, Annie, The Madder Stain: A Psychoanalytic Reading of Thomas Hardy, Leiden: Brill-Rodopi, 2015.

Woolf, Virginia, To the Lighthouse (1972), London: Flamingo, 1995.

\section{NOTES}

1. Some of the paragraphs that follow were a first draft of what was later developed in my book, The Madder Stain: A Psychoanalytic Reading of Thomas Hardy (Ramel 2015). On Bathsheba as a true “object", see p. 74.

2. For further developments on the idea of the lost hat / missing scene as emblematic of objet petit a, see Ramel 2015, 76-77. 


\section{ABSTRACTS}

The object is a central question in Far from the Madding Crowd: whether one thinks of the household goods heaped on the spring wagon that carries Bathsheba (including the precious mirror wrapped in paper), or of the lost object, the missing object (like Bathsheba's hat blown away by the wind), or the surplus object - the object whose incongruous presence disrupts diegetic reality: the Valentine card bought by chance, which Bathsheba does not know what to do with, the watch offered by Troy to Bathsheba, the engagement ring that Boldwood thrusts on Bathsheba, and the extraordinary collection of articles he keeps locked in a closet. The object is also, of course, the object of desire, the woman whom three men seek to appropriate. The object may be part of a series in which each element may be substituted for another, or it may be irreplaceable. It then becomes the Thing, Das Ding, "a thing strong as death", which is an essential element of the tragic.

L'objet est une question centrale dans Far from the Madding Crowd: que l'on songe aux affaires de Bathsheba entassées sur le chariot qui la transporte (y compris le précieux miroir enveloppé dans du papier), ou à l'objet perdu, l'objet qui manque (comme le chapeau de Bathsheba emporté par le vent), ou à l'objet en trop - l'objet dont la présence incongrue dérange la réalité diégétique : la carte de Saint Valentin achetée par hasard, dont Bathsheba ne sait pas quoi faire, la montre que Troy offre à Bathsheba, la bague de fiançailles que Boldwood impose à Bathsheba, et l'extraordinaire collection d'articles qu'il garde sous clé dans une armoire. L'objet c'est aussi, bien sûr, la femme, l'objet du désir que trois hommes tentent de s'approprier. L'objet peut faire partie d'une série dans laquelle chaque élément peut être remplacé par un autre, ou bien il peut être irremplaçable. Il devient alors la Chose, Das Ding, " une chose aussi forte que la mort », qui est un élément essentiel du tragique.

\section{INDEX}

Keywords: object, metonymy, loss, origin, letter, flesh, psychoanalysis, Lacan (Jacques), substitution

Mots-clés: objet, métonymie, perte, origine, lettre, chair, psychanalyse, Lacan (Jacques), substitution

\section{AUTHOR}

\section{ANNIE RAMEL}

Annie Ramel, Professor emeritus at Université Lumière-Lyon 2, is the president of FATHOM (French Association for Thomas Hardy Studies). She wrote her document of "Habilitation" on "L'Autre à l'époque victorienne : Shorthouse, Dickens, Hardy" (2001). Her publications include: Great Expectations, le père ou le pire (Messene, 2000), Rewriting/Reprising: the Paradoxes of Intertextuality, edited in collaboration with Josiane Paccaud-Huguet and Claude Maisonnat 
(Cambridge Scholars Publishing, 2009). She was one of the contributors to Thomas Hardy, Far from the Madding Crowd, edited by Laurence Estanove (Atlande, 2010). She edited part of the papers of the October 2010 Thomas Hardy conference in Lyon, under the title Thomas Hardy, Far from the Madding Crowd (in collaboration with Christian Gutleben, revue Cycnos, 2010). She has written many articles on Charles Dickens, Henry James, George Eliot, Oscar Wilde, but her centre of interest is now Thomas Hardy. She co-edited the first volume of the e-journal FATHOM ("The Letter"), edited the second volume ("Silence"), co-edited the volume on "Liminality" of The Hardy Review (Spring 2013). She has recently published The Madder Stain: A Psychoanalytic Reading of Thomas Hardy (Brill-Rodopi, 2015). 